\title{
Twórczość uczniów I etapu edukacyjnego w opinii nauczycieli
}

Aktywność twórcza dzieci jest potrzebą biologiczną, której zaspokojenie jest niezbędne do prawidłowego rozwoju. Umysł małych dzieci jest otwarty na nowe bodźce, działa swobodnie i wielokierunkowo, do momentu interwencji dorosłego, który chce podporządkować działania dziecka własnym. W procesie twórczym najmłodsi korzystają przede wszystkim z indywidualnego doświadczenia. Przekształcają je i na tej podstawie tworzą lub odnajdują nowe produkty lub myśli, które są cenne dla nich i wywołują w nich silne przeżycie emocjonalne. W związku z tym twórczość dzieci jest naturalną aktywnością i ma przede wszystkim wartość subiektywną. Rolą dorosłego w procesie aktywności twórczej dzieci jest ich inspirowanie i motywowanie. Ważne jest również akceptowanie wytworów dzieci takimi jakimi są, bez nanoszenia poprawek, w celu „upiększenia” lub nadania im bardziej rzeczywistej postaci, aby „lepiej, ładniej” prezentowały się na gazetkach, wystawach, czy też konkursach. Spektrum cech twórcy, które powinny być kształtowane i rozwijane u dzieci obejmuje wrażliwość na problemy, płynność i oryginalność myślenia, szybkość przystosowania się do nowych sytuacji, zdolność do nadawania nowych znaczeń, analizę i syntezę oraz organizację koherentną, która pozwala dopasować odbierane bodźce do

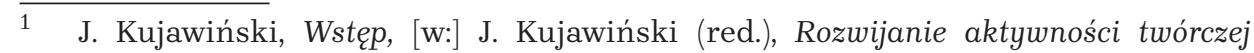
uczniów klas początkowych. Zarys metodyki, WSiP, Warszawa 1990. 
własnej osobowości. Wyposażenie w nie dzieci daje szansę zaistnienia postawy twórczej, która jest warunkiem koniecznym do bycia twórcą 2 .

Twórczość dziecięca ma miejsce bez uświadomienia sobie postawy twórczej. Jest ona bezinteresowna, spontaniczna, ma charakter zabawy i nie opiera się na znanych regułach działania ${ }^{3}$. Odgrywa duże znaczenie w kształtowaniu osobowości dzieci i młodzieży, gdyż stymuluje procesy poznawcze i emocjonalne, jest narzędziem terapeutycznym oraz pozwala wyrazić własne myśli i uczucia. Jest ona definiowana w dwojaki sposób. Twórczość dziecka w znaczeniu węższym dotyczy wytworów plastycznych. W znaczeniu szerszym związana jest $\mathrm{z}$ wielostronną działalnością dziecka, w wyniku której powstają nowe i oryginalne produkty w dziedzinie poznania, sztuki i techniki (zaprojektowanie oryginalnego konkursu, napisanie wierszyka, opowiadania lub skomponowanie piosenki). W przypadku, gdy dziecko rozwiązuje problem, który jest już rozstrzygnięty lub konstruuje przedmioty wynalezione wcześniej mówimy o twórczości wtórnej (subiektywnej) ${ }^{4}$.

\section{Dziedziny twórczej aktywności dzieci}

W literaturze przedmiotu wyróżnia się cztery podstawowe dziedziny twórczości dzieci. Należą do niej aktywność: plastyczna ${ }^{5}$, werbalna ${ }^{6}$

2 R. Gloton, C. Clero, Twórcza aktywność dziecka, przekł. I. Wojnar, WSiP, Warszawa 1985.

3 M. Magda-Adamowicz, Twórczość pedagogiczna nauczycieli w kontekście systemowym. Źródła, koncepcje, identyfikacje, Wydawnictwo Adam Marszałek, Toruń 2015.

4 W. Okoń, Nowy słownik pedagogiczny, Wydawnictwo Akademickie Żak, Warszawa 2004 .

5 J. Uszyńska-Jarmoc, Twórcza aktywność dziecka. Teoria - rzeczywistość - perspektywy rozwoju, Wydawnictwa Trans Humana, Białystok 2003; M. Okraska, Stymulowanie twórczości plastycznej dzieci w wieku przedszkolnym, [w:] A. Tyl (red.), Nauczyciel wczesnej edukacji wobec zmieniającej się rzeczywistości edukacyjnej, kulturowej i spoŁecznej, Wydawnictwo Uniwersytetu Łódzkiego, Łódź 2011.

6 J. Uszyńska-Jarmoc, Twórcza aktywność..; A. Mielech, Twórczość językowa dziecka w okresie wczesnoszkolnym, [w:] R. Piwowarski (red.), Dziecko - sukcesy i porażki, Instytut Badań Edukacyjnych, Warszawa 2007; O. Guzy, Twórcza aktywność werbalna ucznia a kompetencje przestrzenne, [w:] B. Myrdzik, M. Karwatowska (red.), Twórczość w szkole. Rzeczywiste i możliwe aspekty zagadnienia, Wydawnictwo Uniwersytetu Marii Curie-Skłodowskiej, Lublin 2011; Z. Pomirska, Strategia ludyczna w rozwijaniu twórczości językowej dzieci i młodzieży, [w:] ibidem. 
(językowa i literacka), muzyczna ${ }^{7}$ oraz ruchowa ${ }^{8}$. Bogactwo środków wykorzystywanych w rozwijaniu każdej z form aktywności twórczej umożliwia jej kształtowanie i pobudzanie u każdego dziecka. Istotne jest nie tylko oddziaływanie na procesy poznawcze, ale także na sferę emocjonalno-motywacyjną oraz działaniową. Dzieci powinny mieć możliwość prezentowania swoich wytworów na forum, dyskutowania na ich temat oraz przyjmowania informacji krytycznych. Podkreśla się szczególną rolę czynnika motywacyjnego, który decyduje o rozpoczęciu i kontynuowaniu aktywności twórczej. Zadaniem nauczycieli jest organizowanie takich sytuacji, które wywołają u wychowanków emocje sprzyjające podejmowaniu działalności innowacyjnej.

Aktywność plastyczna dzieci i młodzieży jest rozumiana jako czynność psychiczna, która przejawia się w działaniu mającym na celu nadanie określonego kształtu powstającym wytworom. Jej efektem są nie tylko prace wykonane zróżnicowanymi technikami plastycznymi i graficznymi, ale też emocje (radość, duma, ciekawość), które towarzyszą młodym twórcom na wszystkich etapach powstawania dzieła ${ }^{10}$. Ważnym elementem wyzwalania twórczego potencjału jednostki jest stworzenie odpowiedniego klimatu przez osobę prowadzącą zajęcia. Powinien on być oparty na wzajemnym zaufaniu i tolerancji, aby jego uczestnicy mogli odczuwać zadowolenie z udziału w procesie twórczym. Zwiększanie motywacji dziecka w dziedzinie twórczości plastycznej odbywa się poprzez zachętę, umiejętną pochwałę, wzbogacanie przeżyć dziecka, ale też zorganizowanie odpowiednich warunków materialnych, czasowych i przestrzennych. Czynnikami, które blokują dzieci przed swobodnym wyrażaniem siebie w pracach plastycznych jest lęk przed ośmieszeniem i krytyką ze strony rówieśników lub nauczyciela oraz narzucanie tematu prac i pomysłu ich realizacji ${ }^{11}$.

7 J. Uszyńska-Jarmoc, Twórcza aktywność...; A. Kędzierska, Formy muzycznej aktywności twórczej na zajęciach kształcenia słuchu, [w:] S. Popek, R.E. Bernacka, C.W. Domański, B. Gawda, D. Turska, A.M. Zawadzka (red.), Psychologia twórczości. Nowe horyzonty, Wydawnictwo Uniwersytetu Marii Curie-Skłodowskiej, Lublin 2009.

8 J. Gnitecki, B. Grochowalska, Problematyka metodyczna rozwijania aktywności twórczej w nauczaniu początkowym. Kultura fizyczna, [w:] J. Kujawiński (red.), Rozwijanie aktywności...; J. Uszyńska-Jarmoc, Twórcza aktywność...

$9 \quad$ K.J. Szmidt, Pedagogika twórczości, GWP, Gdańsk 2007.

10 J. Uszyńska-Jarmoc, Twórcza aktywność...

11 M. Przetacznik-Gierowska, M. Tyszkowa, Psychologia rozwoju człowieka, Wydawnictwo Naukowe PWN, Warszawa 1996. 
Młodszy wiek szkolny jest ostatnim etapem, w którym aktywność plastyczna stanowi spontaniczną ekspresję kształtującą osobowość dziecka. W jego pracach nadal widoczne są emocje i uczucia, które towarzyszą mu w poznawaniu i eksploracji świata. Jednak w tej fazie rozpoczyna się stopniowy zanik wyobraźni twórczej w porównaniu do poziomu rozwoju pamięci i myślenia, w wyniku którego w wieku około 10-11 roku życia następuje regres swobodnej ekspresji na rzecz kopiowania i stereotypowości. Dzieci nie korzystają ze swojej wyobraźni i indywidualnego obrazu świata. Ich miejsce zajmuje wszystko to, co jest obserwowalne, materialne i oparte na realistycznej wiedzy ${ }^{12}$. Znaczenie aktywności plastycznej w rozwoju dziecka jest złożone i pełni szczególną rolę. Proces tworzenia wyzwala emocje i przeżycia, pobudza wyobraźnię i inicjatywę, uwrażliwia dziecko na zjawiska zachodzące w rzeczywistości, daje szansę na kontakt ze światem sztuki. Uczy także współpracy, kształtuje osobowość, a poprzez to przygotowuje do pełnienia ról społecznych w przyszłości. W akcie tworzenia dziecko najpełniej opisuje swój stosunek do siebie samego, najbliższych i otaczającego świata, a efektem tego są prace odzwierciedlające stan jego psychiki ${ }^{13}$.

Twórczość werbalna rozpatrywana jest w dwóch nakładających się na siebie kontekstach: jako twórcze uczenie się języka i jako jego twórcze używanie ${ }^{14}$. Dziecko nie opanuje języka, podobnie jak i innych czynności, tylko poprzez naśladownictwo, niezbędne jest również jego konstruowanie. Aktywność twórcza w tym zakresie jest konieczna do nawiązywania kontaktów społecznych, podejmowania działań eksploracyjnych i wyrażania siebie. Twórcze używanie języka przejawia się m.in. przez tworzenie nowych słów, wymyślanie opowiadań i tekstów. Konstruowanie neologizmów pozwala dzieciom na porozumiewanie się z otoczeniem i wyrażenie własnych myśli. W ten sposób wypełniają lukę w ograniczonym zasobie słownictwa. Ta forma komunikacji jest szczególnie aktywna u dzieci do piątego roku życia, natomiast później stopniowo się zmniejsza. Nie oznacza to jednak, że maleje zdolność dzieci w tej dziedzinie. Wręcz przeciwnie, wraz z wiekiem w sytuacjach eksperymentalnych czynią to coraz sprawniej, jednak w codziennej

\footnotetext{
12 D. Turska, Dynamika postawy twórczej a typ kształcenia szkolnego młodzieży, Wydawnictwo Uniwersytetu Marii Curie-Skłodowskiej, Lublin 1994.

13 M. Okraska, Stymulowanie twórczości plastycznej...

14 J. Uszyńska-Jarmoc, Twórcza aktywność...
} 
komunikacji używają znanych zwrotów ${ }^{15}$. Wymyślanie opowiadań i tekstów jest kolejnym przejawem twórczego używania języka. Dzieci tworzą je na bazie zasłyszanych historii lub konstruują według własnych pomysłów. Prace dzieci w młodszym wieku szkolnym charakteryzują się kreatywnością w obszarze formy i treści, natomiast twórcza aktywność dzieci starszych jest na dużo niższym poziomie ${ }^{16}$. Systematyczne czytanie dzieciom bajek stymuluje rozwój ich wyobraźni twórczej, motywuje do działania, odkrywania i tworzenia, a także staje się emocjonalną podstawą do tworzenia tekstu własnego ${ }^{17}$.

Kolejnym obszarem dziecięcej twórczości jest aktywność muzyczna. Polega ona na celowym i świadomym działaniu twórczym, w wyniku którego powstaje nowy utwór muzyczny lub układ choreograficzny. Podstawowym celem pobudzania działalności dzieci w tym zakresie jest kształtowanie zainteresowań utworami muzycznymi oraz odnajdywanie przyjemności w ich słuchaniu. Muzyka rozwija osobowość dziecka, pobudza kształtowanie wyobraźni i wrażliwości estetycznej. Zachęca do improwizacji wokalnej i instrumentalnej. Kontakt z odpowiednio dobranymi utworami stymuluje do podejmowania aktywności, jak też daje możliwość przemyślenia podejmowanych działań. W nauczaniu wychowania muzycznego stosuje się zróżnicowane instrumenty muzyczne i utwory, do interpretacji których zapraszane są dzieci. Wyzwala to potrzebę wyrażania własnych emocji i pomysłowość oraz stwarza dogodne sytuacje do tworzenia ${ }^{18}$.

Z aktywnością muzyczną związana jest aktywność ruchowa dzieci. Jest ona naturalną potrzebą każdego człowieka, podejmowaną celowo

15 M. Przetacznik-Gierowska, M. Tyszkowa, Psychologia rozwoju...; K. Gąsiorek, Uczeń w wieku wczesnoszkolnym jako twórca języka, [w:] B. Myrdzik, M. Karwatowska (red.), Twórczość w szkole...; O. Przybyła, Kompetencje tekstotwórcze uczniów klas początkowych w świetle sensoryczno-motorycznego kształcenia dla mowy i języka, [w:] ibidem.

16 A. Guzy, Twórcza aktywność...

17 D. Dziedziewicz, Śladami wyobraźni twórczej. Bajka i działania plastyczne jako metody stymulowania i analizowania twórczości najmłodszych, [w:] M. Karwowski, A. Gajda (red.), Kreatywność (nie)tylko w klasie szkolnej, Wydawnictwo Akademii Pedagogiki Specjalnej, Warszawa 2010; B. Niesporek-Szamburska, Pisanie baśni - od motywacji do kształcenia kompetencji tekstotwórczej, [w:] B. Myrdzik, M. Karwatowska (red.), Twórczość w szkole...

18 J. Uszyńska-Jarmoc, Twórcza aktywność..; A. Kędzierska, Formy muzycznej aktywności twórczej na zajęciach kształcenia słuchu, [w:] S. Popek, R.E. Bernacka, C.W. Domański, B. Gawda, D. Turska, A.M. Zawadzka (red.) Psychologia twórczości... 
lub spontanicznie każdego dnia. Do realizowania zajęć ruchowych można wykorzystywać różnorodne i nietypowe środki, jak i metody dydaktyczne, np. opowiadania, utwory muzyczne. Wyzwalają one w dzieciach twórczy potencjał i zaangażowanie. Systematycznie prowadzone i zróżnicowane zajęcia ruchowe wpływają na rozwój dziecka. Ruchową aktywność dzieci uznaje się za twórczą, jeśli jest podejmowana chętnie oraz opiera się na własnych pomysłach i sposobach realizacji ${ }^{19}$. Jedną z jej form jest zabawa, która

jest działaniem wykonywanym dla własnej przyjemności, a opartym na udziale wyobraźni,tworzącejnowąrzeczywistość.Choćdziałaniem tym rządząreguły(...)maono charakter twórczy i prowadzi do samodzielnego poznawania i przekształcania rzeczywistości ${ }^{20}$.

Jest ona przejawem aktywności dziecka, wyznacznikiem jego rozwoju i obok nauki, podstawową formą jego działalności ${ }^{21}$.

Nauczyciele wczesnej edukacji jako najważniejszą funkcję gier i zabaw ruchowych wskazują funkcję wychowawczą. Wysoko cenione jest także kształcące i poznawcze znaczenie aktywności fizycznej, natomiast tylko nieliczni zauważają i doceniają jej socjalną i hedonistyczną rolę. W ich opinii ćwiczenia sportowe wpływają przede wszystkim na rozwijanie umiejętności współpracy w grupie, doskonalenie sprawności fizycznej oraz uczą zasad bezpieczeństwa. Nauczyciele nie dostrzegają w zabawach ruchowych możliwości rozwijania i stymulowania twórczej aktywności ${ }^{22}$.

\section{Rozwijanie aktywności twórczej dzieci w młodszym wieku szkolnym}

Podstawowym warunkiem zaistnienia twórczej aktywności dzieci są sprzyjające cechy trzech płaszczyzn. Pierwsza z nich, materialna,

\footnotetext{
9 J. Gnitecki, B. Grochowalska, Problematyka metodyczna...

20 W. Okoń, Zabawa a rzeczywistość, Wydawnictwo Akademickie Żak, Warszawa 1987, s. 44.

21 M. Przetacznik-Gierowska, M. Tyszkowa, Psychologia rozwoju...

22 A. Kaźmierczak, Wychowawcza rola zabaw i gier ruchowych $w$ opinii nauczycieli kształcenia zintegrowanego, [w:] W. Leżańska (red.), Nauczyciel wczesnej edukacji $w$ kontekście zmian edukacyjnych, Wydawnictwo Uniwersytetu Łódzkiego, Łódź 2009.
} 
to umożliwienie dziecku działania z wykorzystaniem zróżnicowanych materiałów. Kolejna, czyli emocjonalna, przejawia się w tworzeniu klimatu zapewniającego poczucie bezpieczeństwa, natomiast metodyczną, cechuje się umiejętne stymulowanie, inspirowanie i kierowanie aktywnością dziecka. Oprócz tego niezbędna jest również silna motywacja w dążeniu do celu, wysoki poziom emocji dodatnich, pozytywny obraz samego siebie oraz odpowiednia postawa rodziców wobec dzieci $^{23}$.

W zależności od wieku dziecka różne są motywy podejmowanej przez niego aktywności twórczej. Dzieci młodsze przystępują do niej najczęściej samoistnie, kierowane ciekawością czy chęcią zabawy i do jej realizacji nie potrzebują wzmocnień zewnętrznych. Jest to sytuacja odwrotna niż u dzieci starszych, które potrzebują nagród i rywalizacji do rozbudzenia w nich aktywności twórczej ${ }^{24}$. Środowisko zewnętrze, do którego zaliczamy np. rodzinę, grupę rówieśniczą, szkołę wywiera wpływ na rozwijanie aktywności twórczej dzieci, ale może również stać się czynnikiem blokującym ujawnianie predyspozycji twórczych.

Edukacja wczesnoszkolna skierowana na rozwijanie twórczej aktywności dzieci wymaga odpowiednio zorganizowanego procesu dydaktyczno-wychowawczego. W jego projektowaniu uwzględnia się aktywność spontaniczną, inspirowaną i stymulowaną dzieci oraz samodzielne rozwiązywanie zadań problemowych, zarówno teoretycznych, jak i praktycznych związanych $\mathrm{z}$ otoczeniem i potrzebami dziecka. Działania te przebiegają w atmosferze szacunku, życzliwości, swobody oraz współpracy z innymi uczniami. W wyniku twórczej aktywności dzieci powstaje produkt, który jest nowy dla działającego podmiotu i jednocześnie pożyteczny, ponieważ w ten sposób uczeń rozwija swoje zdolności i wiedzę oraz wzrasta jego samoocena ${ }^{25}$.

Szkoła jest miejscem, które nie sprzyja twórczości ponieważ uczniowie uczą się w niej konformizmu oraz przekazuje się im zbyt dużą ilość informacji, natomiast $\mathrm{w}$ niewielkim zakresie stymuluje się ich

23 A. Klim-Klimaszewska, Twórcza aktywność, [w:] T. Pilch (red.), Encyklopedia pedagogiczna XXI wieku, t. 6, Wydawnictwo Akademickie Żak, Warszawa 2007.

24 K.J. Szmidt, Mity na temat twórczości dzieci i próba ich dekonspiracji, [w:] K.J. Szmidt, W. Ligęza (red.), Twórczość dzieci i młodzieży. Stymulowanie, badanie, wsparcie, Ośrodek Twórczej Edukacji „Kangur”, Kraków 2009.

25 J. Kujawiński, Rozwijanie aktywności twórczej uczniów klas początkowych, [w:] J. Kujawiński (red.), Rozwijanie aktywności... 
myślenie, wyobraźnię, czy też dociekliwość poznawczą ${ }^{26}$. W przekazie treści nauczyciele skupiają się przede wszystkim na zawartości merytorycznej podręczników, bez uwzględniania zainteresowań uczniów. Do czynników hamujących lub ograniczających rozwój procesów twórczych zalicza się też przeszkody związane z celami i treściami nauczania oraz wychowania, przeszkody związane z postawami nauczycieli i metodami nauczania, przeszkody związane z postawami uczniów oraz przeszkody związane z bazą lokalową i wyposażeniem szkół ${ }^{27}$.

Zaufanie, jakim uczniowie darzą nauczyciela jest jednym z elementów niezbędnych do podejmowania przez nich zachowań twórczych. Do zachowań nauczycieli edukacji wczesnoszkolnej, które sprzyjają budowaniu atmosfery opartej na zaufaniu należą m.in.: cierpliwość i sprawiedliwość, łatwość nawiązywania kontaktu oraz prowadzenie zajęć w sposób ciekawy i urozmaicony. Natomiast nauczyciel, którego cechuje nerwowość, porywczość, wybuchowość, gwałtowność, nie potrafi nawiązać kontaktu z dziećmi i wzbudza w nich lęk ${ }^{28}$.

Pierwsze badania, które dotyczyły rozwijania zdolności twórczych w procesie edukacji zostały przeprowadzone przez Paula Torrance. Uważał on, że wszystkie dzieci dysponują twórczym potencjałem, jednak przez niewłaściwe zachowania nauczycieli ulega on zahamowaniu. Wychowawca nie musi uczyć dzieci twórczości, wystarczy, żeby im nie przeszkadzał. Myślenie twórcze dzieci jest rozwijane, gdy nauczyciele szkół podstawowych przejawiają odpowiednie zachowania w stosunku do uczniów, na które składają się: szacunek do ich niezwykłych pytań i wobec ich niezwykłych pomysłów, okazywanie, że ich pomysły są wartościowe, stwarzanie warunków do działania bez oceny oraz wskazywanie wad i zalet pracy w miejsce uogólnionych ocen ${ }^{29}$.

Wyniki badań wskazują, że w kolejnych latach nauki szkolnej uczniowie osiągają gorsze rezultaty $\mathrm{w}$ testach twórczości ${ }^{30}$. Istnieje

26 E. Nęcka, Psychologia twórczości, GWP, Gdańsk 2003.

27 K.J. Szmidt, Pedagogika...

28 E. Marek, Nauczyciel wczesnej edukacji w zmieniającej się szkole, [w:] B. Muchacka, M. Szymański (red.), Nauczyciel w świecie współczesnym, Oficyna Wydawnicza „Impuls", Kraków 2008.

29 E. Nęcka, Psychologia...; M. Magda-Adamowicz, Uwarunkowania efektywności ksztatcenia nauczycieli klas I-III w zakresie twórczości pedagogicznej, Oficyna Wydawnicza Uniwersytetu Zielonogórskiego, Zielona Góra 2009.

30 J. Dobrołowicz, Kreatywność uczniów a ich osiagnięcia szkolne, Wydawnictwo Akademii Świętokrzyskiej, Kielce 2002. 
także związek pomiędzy wysokim poziomem kreatywności a uzyskiwaniem wysokich ocen z matematyki i języka polskiego, przy czym duża grupa uczniów kreatywnych osiąga niskie wyniki nauczania. Uczniowie zdobywający wysokie wyniki nauczania są inteligentni, jednak nie wykazują twórczych predyspozycji, natomiast uczniowie jednocześnie twórczy i inteligentni osiągają niższą średnią ocen ${ }^{31}$. Szkoła oceniana jest przez młodzież pozytywnie w aspektach, które są ważne dla tworzenia klimatu sprzyjającego twórczości. Deklarują oni, że nauczyciele stosują twórcze metody pracy, akceptują realizowanie inicjatyw uczniowskich oraz prowadzą zajęcia o charakterze twórczym. Osoby twórcze, w przeciwieństwie do odtwórczych, uważają, że środowisko szkolne inspiruje rozwijanie takich cech, jak: samodzielność, wytrwałość, niezależność i przedsiębiorczość, które wpływają na poczucie sprawowania kontroli nad własnym życiem ${ }^{32}$.

\section{Założenia metodologiczne badań własnych}

Prezentowane w tekście wyniki badań pochodzą z drugiego etapu projektu, który dotyczył zawodu nauczyciela oraz różnych kwestii społecznych widzianych oczami tej grupy społecznej. Pierwszy etap badań polegał na przeprowadzeniu badań ilościowych wśród nauczycieli pracujących w białostockich publicznych szkołach podstawowych z dziećmi w młodszym wieku szkolnym. Objęłam nimi 120 nauczycieli edukacji wczesnoszkolnej i wychowawców świetlicy pracujących w trzynastu placówkach. Jednak ze względu na niepełne uzupełnienie kwestionariuszy, które mogłoby doprowadzić do nierzetelnych wniosków, do dalszej analizy zakwalifikowałam 112 kompletów narzędzi badawczych. Drugi etap badań, polegał na przeprowadzeniu badań jakościowych wśród nauczycielek, które w pierwszym etapie wykazały wysokie preferencje dla twórczych orientacji życiowych. W tym etapie

31 D. Turska, Nihil novi w edukacji. Rzecz o kreatywnym prymusie polskiej szkoły okresu reform, [w:] W. Dobrołowicz, K.J. Szmidt, I. Pufal-Struzik, U. Ostrowska, J. Gralewski (red.), Kreatywność kluczem do sukcesu w edukacji, Wszechnica Polska Szkoła Wyższa Towarzystwa Wiedzy Powszechnej, Warszawa 2006.

32 M. Łączyk, Środowisko wychowawcze a osobowość twórcza - diagnoza uwarunkowań postaw twórczych studentów na podstawie badań własnych, [w:] S. Popek, R.E. Bernacka, C.W. Domański, B. Gawda, D. Turska, A.M. Zawadzka (red.), Psychologia twórczości... 
badań wykorzystałam metodę indywidualnych przypadków, której celem jest analiza określonych zjawisk wychowawczych pryzmat jednostkowych biografii ludzkich ${ }^{33}$, natomiast techniką był wywiad w postaci kwestionariusza wywiadu. Wywiady, które trwały od prawie jednej do ponad dwóch godzin, prowadziłam w domu rozmówców lub w miejscu ich pracy po zakończonych obowiązkach służbowych. Były one najczęściej kontynuowane, nawet do ponad trzech godzin, zwłaszcza po wyłączeniu dyktafonu, i obejmowały również inne nie poruszone w wywiadzie zagadnienia oraz problemy, z którymi na co dzień borykają się nauczyciele. Do analizy danych jakościowych zastosowałam koncepcję Matthew B. Milesa i A. Michaela Hubermana ${ }^{34}$, na którą składają się następujące działania: redukcja danych, reprezentowanie danych oraz wyprowadzanie i weryfikacja wniosków.

Większość nauczycielek biorąc udział już w pierwszym etapie badań, nie wyrażała zgody na objęcie ich dalszymi badaniami. Przejawiało się to, albo w bezpośrednim komunikacie zanotowanym w kwestionariuszu ankiety „nie wyrażam zgody”, „nie zgadzam się”, albo też poprzez niepodanie swojego numeru telefonu, co uniemożliwiło nawiązanie dalszego kontaktu. Z tego powodu badania jakościowe zostały przeprowadzone wśród sześciu nauczycielek preferujących twórcze orientacje życiowe. Połowę z nich stanowiły nauczycielki edukacji wczesnoszkolnej, a połowę wychowawczynie świetlicy. Taki dobór nauczycielek do drugiego etapu badań ma również uzasadnienie w uzyskanych wynikach w zakresie preferencji twórczych orientacji życiowych. Pomimo że wychowawczynie świetlicy w pierwszym etapie badań reprezentowały nieco ponad jedną trzecią respondentów (34,82\% badanych), to stanowiły one 46,87\% nauczycielek o twórczych orientacjach życiowych. Wyznacznikiem twórczych orientacji życiowych, specyficznych dla danej jednostki, jest przede wszystkim sposób jej funkcjonowania w społeczeństwie, oparty na aktualizowaniu własnego potencjału rozwojowego, kreowaniu siebie i otaczającego świata. Twórcze orientacje życiowe są zawsze konsekwencją świadomego wyboru i przejawiają się w osobistym i zaangażowanym sposobie pełnienia codziennych

33 T. Pilch, Zasady badań pedagogicznych, Wydawnictwo Akademickie Żak, Warszawa 1998.

34 M.B. Miles i A.M. Huberman, Analiza danych jakościowych, przekł. S. Zabielski, Wydawnictwo Trans Humana, Białystok 2000. 
obowiązków. Ich płaszczyznę pedagogiczną wyznacza teoria twórczości codziennej, w której liczą się, nie szczególne uzdolnienia i predyspozycje jednostki, a jej samoświadomość. Twórczość codzienna przejawia się we wszystkich dziedzinach ludzkiej aktywności, a jej efektem są wytwory i zachowania, które są wartościowe dla działającego podmiotu. Warunkiem jej zaistnienia jest jej zakorzenienie w świadomości aksjologicznej jednostki ${ }^{35}$. Przekonanie nauczyciela, że twórczość jest ważną wartością w jego życiu i w życiu jego uczniów powoduje, że odczuwa on potrzebą stałego rozwoju, poszukuje twórczych rozwiązań i inspiruje uczniów do pracy nad własną postawą wobec świata i siebie ${ }^{36}$. Z tego też powodu preferowanie przez nauczycieli twórczego stylu życia i podejścia do pracy pedagogicznej jest niezwykle ważnym aspektem ich pracy oraz może wpływać na efektywność ich działalności edukacyjnej.

Tabela 1. Charakterystyka badanych nauczycielek

\begin{tabular}{|l|l|c|l|}
\hline \multicolumn{1}{|c|}{ Imię* } & \multicolumn{1}{|c|}{ Stanowisko pracy } & $\begin{array}{c}\text { Staż } \\
\text { pracy }\end{array}$ & \multicolumn{1}{c|}{$\begin{array}{c}\text { Stopień awansu } \\
\text { zawodowego }\end{array}$} \\
\hline Anna & $\begin{array}{l}\text { Wychowawczyni świetlicy } \\
\text { szkolnej }\end{array}$ & 13 lat & $\begin{array}{l}\text { Nauczyciel } \\
\text { dyplomowany }\end{array}$ \\
\hline Agnieszka & $\begin{array}{l}\text { Nauczyciel edukacji } \\
\text { wczesnoszkolnej }\end{array}$ & 25 lat & $\begin{array}{l}\text { Nauczyciel } \\
\text { dyplomowany }\end{array}$ \\
\hline Elżbieta & $\begin{array}{l}\text { Nauczyciel edukacji } \\
\text { wczesnoszkolnej }\end{array}$ & 6 lat & $\begin{array}{l}\text { Nauczyciel } \\
\text { kontraktowy }\end{array}$ \\
\hline Katarzyna & $\begin{array}{l}\text { Wychowawczyni świetlicy } \\
\text { szkolnej }\end{array}$ & 30 lat & $\begin{array}{l}\text { Nauczyciel } \\
\text { dyplomowany }\end{array}$ \\
\hline Małgorzata & $\begin{array}{l}\text { Nauczyciel edukacji } \\
\text { wczesnoszkolnej }\end{array}$ & $\begin{array}{l}\text { Nauczyciel } \\
\text { dyplomowany }\end{array}$ \\
\hline Martyna & $\begin{array}{l}\text { Wychowawczyni świetlicy } \\
\text { szkolnej }\end{array}$ & $\begin{array}{l}\text { Nauczyciel } \\
\text { kontraktowy }\end{array}$ \\
\hline
\end{tabular}

* Ze względu na zachowanie anonimowości badanych, imiona nauczycielek zostały zmienione. Źródło: opracowanie własne.

35 A. Cudowska, Twórcze orientacje życiowe w dialogu edukacyjnym. Studium teoretyczno-empiryczne, Wydawnictwo Trans Humana, Białystok 2014.

36 Eadem, Twórczość pedagogiczna nauczyciela w społeczeństwie wiedzy, [w:] W. Horyń, J. Maciejewski (red.), Nauczyciel andragog w społeczeństwie wiedzy, Wydawnictwo Uniwersytetu Wrocławskiego, Wrocław 2007. 
Nauczycielki uczestniczące w drugim etapie badań posiadały wykształcenie wyższe magisterskie, uzupełnione kursami kwalifikacyjnymi lub studiami podyplomowymi. Ich staż pracy był bardzo zróżnicowany i wynosił od 5 do 30 lat. Cztery osoby posiadały stopień awansu zawodowego nauczyciela dyplomowanego, natomiast tylko dwie były nauczycielami kontraktowymi w trakcie stażu na stopień nauczyciela mianowanego (tabela 1). Wszystkie nauczycielki posiadały doświadczenie $\mathrm{w}$ pracy z uczniami posiadającymi orzeczenie o potrzebie kształcenia specjalnego wydane przez poradnie psychologiczno-pedagogiczne ze względu na niepełnosprawność.

\section{Twórczość uczniów I etapu edukacyjnego - wyniki badań własnych}

Twórczy uczeń w opinii nauczycielek to osoba, która charakteryzuje się samodzielnym myśleniem, działaniem oraz poszukiwaniem nowych rozwiązań. Nie boi się wyrażać własnych opinii, a jeżeli zaistnieje potrzeba potrafi bronić swojego stanowiska stosując konkretne argumenty. Jest otwarty na wszystko, co nowe oraz potrafi krytycznie spojrzeć na siebie i swoją pracę. Tylko jedna nauczycielka zauważyła brak zależności pomiędzy wynikami nauczania a kreatywnością ucznia. „Wyniki w nauce przedmiotowej nie równają się z twórczością dziecka. Według mnie to nie idzie ze sobą w parze" (Anna). W swojej narracji zwraca uwagę, że zaangażowanie, z jakim najmłodsi uczestniczą i urozmaicają zajęcia, świadczą o ich twórczości. W opinii Małgorzaty istotnym wyznacznikiem twórczości jest wrażliwość i poczucie estetyki. Zdaniem nauczycielek, kreatywny uczeń jest też elastycznym indywidualistą (Agnieszka) oraz charakteryzuje go energia (Martyna). Zauważają też, że uczniowie twórczy nie mają trudności w relacjach z rówieśnikami (Katarzyna, Anna i Agnieszka), a nawet radzą sobie dużo lepiej niż dzieci, które są mało kreatywne (Martyna). O sukcesie w kontaktach z innymi, zdaniem Elżbiety i Małgorzaty, nie decyduje stopień twórczości ucznia, a jego osobowość i umiejętność nawiązania kontaktu. Wskazane przez nauczycielki cechy twórczego ucznia w znacznej części pokrywają się z teoriami naukowymi na ten temat ${ }^{37}$. Najwięcej zastrzeżeń budzi jednak ich opinia na temat relacji takiego

$37 \quad$ K.J. Szmidt, Pedagogika... 
ucznia z innymi, gdyż w świetle literatury przedmiotu „dzieci utalentowane twórczo mają zawsze wiele do powiedzenia, dlatego w swym środowisku są bardzo dominujące. Nie uznają autorytetów i reagują silnie na wszystkie ograniczenia"38.

Nauczycielki uważają, że rodzaj niepełnosprawności dziecka wpływa na przejawianą przez niego twórczość. Ich zdaniem, kreatywne zachowania nie występują u osób dotkniętych głębokimi dysfunkcjami, takimi jak np. niepełnosprawność intelektualna. Jedynie wychowawczynie świetlicy (Anna i Katarzyna) przypisują twórcze zachowania wszystkim uczniom i są zdania, że na ich uzewnętrznienie wpływa przede wszystkim odpowiedni stosunek nauczyciela oraz umiejętność dotarcia do dziecka i pokierowania jego rozwojem.

Najbardziej popularną formą prezentowania twórczych osiągnięć uczniów są wystawy i dekoracje przygotowanych przez dzieci prac oraz udział w różnego rodzaju konkursach i przeglądach. „Tworzenie wystawek, dekoracji z prac wykonanych przez uczniów daje możliwość pokazania rodzicom, koleżankom, kolegom swojej pracy" (Anna).

Gazetki na holu, dekoracje, wysyłamy je na różnego rodzaju przeglądy, na które dzieci są zapraszane. Był przegląd w kinie Forum, gdzie dzieci mogły obejrzeć swoje prace, w Miejskim Domu Kultury są też organizowane wystawy. Wszędzie tam, gdzie jest to możliwe. Na naszym osiedlu, w klubie osiedlowym, były prezentowane nasze prace. Także jest to kwestią współpracy z lokalną społecznością (Katarzyna).

Takie działania podejmują wszystkie nauczycielki, które uczestniczyły w drugim etapie badań. Dodatkowo nauczycielki organizują kiermasze charytatywne, z których dochód przeznaczany jest na rzecz organizacji pożytku publicznego (Agnieszka i Anna), prezentują wytwory dzieci na stronie internetowej szkoły (Agnieszka), czy też redagują wraz z uczniami biuletyn ekologiczny (Małgorzata). Nauczycielki przygotowują uczniów przede wszystkim do konkursów plastycznych, recytatorskich i teatralnych. Najbardziej krytyczny stosunek wobec takiej formy prezentowania możliwości dzieci przejawia wychowawczyni świetlicy „Wolę zachować prace dzieci, wyeksponować, żebyśmy my to widzieli jako grupa, niż żeby były oceniane przez komisję" (Martyna). Jej sympatią cieszą się konkursy wiedzy. Zarówno ona, jak i Elżbieta, zauważają, że choć nie przyczyniają się do kreatywnego rozwoju dzieci, to

$\overline{38}$ Ibidem, s. 186. 
jednak wzbogacają wiedzę ucznia. Na antytwórczy aspekt konkursów wiedzy zwracają również uwagę pozostałe wychowawczynie świetlicy. Przeciwnego zdania są nauczycielki edukacji wczesnoszkolnej (Małgorzata i Agnieszka). „Rozwijanie twórczości jest też zadaniem konkursów, nawet konkursów wiedzy. My sobie zdajemy sprawę, że może dzieci tam wiele nie zdziałają, wysokiego miejsca nie zajmą, ale już się oswajają z atmosferą konkursu. Próbują swoich sił. Konkursy są też po to, żeby zahartować na niepowodzenia" (Agnieszka).

Twórcza aktywność dzieci przejawia się w ich działalności plastycznej, pracach pisemnych, zabawach ruchowych i zajęciach artystycznych. Wszystkie cztery formy pojawiły się w wypowiedziach nauczycielek. Najbardziej krytyczny stosunek do twórczości dzieci prezentuje Elżbieta. Jej zdaniem, uwidacznia się ona tylko i wyłącznie w zajęciach teatralnych, natomiast w przypadku pozostałych trzech obszarów niewiele dzieci wykazuje twórcze uzdolnienia. Według Agnieszki, twórczość dzieci zaistnieje pod warunkiem, że zakres pracy plastycznej, pisemnej i zabaw ruchowych nie będzie narzucony przez osobę prowadzącą. Jest to możliwe tylko przy pracach wykonywanych na dowolny temat i braku jakichkolwiek sugestii nauczyciela. Nauczycielki zgodnie przyznają, że nie oceniają prac plastycznych dzieci i starają się w każdej dostrzec coś ciekawego lub wartościowego. Swoją dezaprobatę wyrażają jedynie w przypadku dostrzeżenia braku zaangażowania dziecka w wykonanie pracy. Małgorzata, jako jedyna przyznała, że sugeruje dzieciom elementy, które należy poprawić, aby praca stała się bardziej atrakcyjna. Wszystkie pozwalają dokończyć dzieciom rozpoczętą pracę plastyczną. Jednak nauczycielki edukacji wczesnoszkolnej starają się tak organizować zajęcia, żeby stało się to podczas lekcji. Kończenie prac w domu uważają za ostateczność. Nauczycielki świetlicy umożliwiają uczniom kilkakrotne powracanie do rozpoczętej pracy. Wiążą to nie tylko ze specyfiką pracy w świetlicy, ale także uznają za przejaw twórczości dziecka. „Owszem jesteśmy ograniczeni czasowo, natomiast zawsze ta praca może być rozłożona na dłużej i dziecko otrzymuje tyle czasu ile potrzebuje na skończenie danej pracy" (Anna).

W opinii nauczycielek twórczość dzieci w działalności plastycznej uobecnia się przede wszystkim w przekazie wytworu i zawartych $\mathrm{w}$ nim emocjach, estetyce wykonania pracy oraz w doborze barw. Ich zdaniem, ważna jest również samodzielność wykonania, pomysłowość i oryginalność pracy. Jedynie Elżbieta uważa, że praca twórcza 
powinna być wiernym odzwierciedleniem rzeczywistości. W narracjach nauczycielek udoskonalanie znanych zabaw oraz urozmaicanie ich o nowe elementy jest przejawem twórczości dzieci w zajęciach ruchowym. „Dzieci same sobie wymyślają zabawy, wnoszą coś od siebie” (Małgorzata). „Szczególnie, jeśli same bawią się w różne zabawy, muszą się dogadać, coś tam wymyślić” (Agnieszka). „Na naszych zajęciach te zabawy ruchowe są udoskonalane przez same dzieci. Jeśli dzieci mają jakiś pomysł, że można by to było zrobić tak i tak, to jest właśnie według mnie przejaw twórczego myślenia u dzieci" (Anna).

Kreatywność w pracach pisemnych widoczna jest w tworzonych przez nie utworach. Są to zarówno krótkie formy takie jak wierszyki, rymowanki, jak również dłuższe opowiadania. Małgorzata zauważa, że prace i wypowiedzi uczniów twórczych składają się z rozbudowanych i ciekawych zdań. Twórczość pisemna dzieci, zdaniem Agnieszki, widoczna jest głównie w swobodnych tekstach, które piszą przede wszystkim starsi uczniowie. Krytyczny stosunek wobec tego rodzaju kreatywności przejawia Elżbieta. Jej zdaniem tylko nieliczne dzieci wykazują się oryginalnością i pomysłowością w tym zakresie.

Wszystkie nauczycielki preferujące twórcze orientacje życiowe uważają, że twórczość dzieci widoczna jest w występach teatralnych i muzycznych. Uobecnia się ona, ich zdaniem, w wyborze i tworzeniu przez dzieci strojów oraz w sposobie odgrywania roli. Twórcze dzieci wnoszą także swoje sugestie do wyglądu scenografii oraz wybierają scenariusze zajęć. Jedynie Anna zauważa, że twórczość to też tworzenie własnych układów tanecznych i melodii oraz modyfikowanie znanych utworów. Niezbędne do przedstawień dekoracje i rekwizyty Martyna tworzy wspólnie z dziećmi i rodzicami. Jest otwarta na ich sugestie oraz pomysły w tym zakresie. Odmiennie postępują nauczycielki edukacji wczesnoszkolnej (Elżbieta i Małgorzata), które uważają, że tylko ich wizja jest właściwa i wykonują je samodzielnie. „Dekoracja to już moje zadanie, ja wiem jak ma wyglądać...” (Małgorzata). Przez takie działanie nauczycielki uniemożliwiają dzieciom zaprezentowanie swoich pomysłów i blokują ich twórczą aktywność w tym obszarze.

Głównymi inhibitorami twórczych zachowań dzieci, zdaniem nauczycielek preferujących twórcze orientacje życiowe, są postawy nauczyciela oraz innych uczniów. Wszystkie nauczycielki uczestniczące w drugim etapie badań wskazały te dwa czynniki blokujące kreatywność dzieci. Nauczycieli obwiniają przede wszystkim o dominujący styl 
nauczania i niedostrzeganie potrzeb dzieci. Schematyzm, nastawienie na dydaktykę oraz wprowadzane przez nich zasady uniemożliwiają rozwijanie twórczości uczniów. Uczniowie, którzy nie interesują się nauką oraz nie wykazują żadnej konstruktywnej aktywności, krytykują działania i wytwory rówieśników blokują kreatywny rozwój koleżanek i kolegów. Szansą na zminimalizowanie negatywnych wpływów rówieśników, zdaniem nauczycielek, jest przede wszystkim odpowiednia postawa nauczyciela.

Opinie nauczycielek na temat związku bazy lokalowej placówki i jej wyposażenia z podejmowaniem przez dzieci działań twórczych są podzielone. Nauczycielki edukacji wczesnoszkolnej, uważają, że brak pracowni i środków dydaktycznych, nieprzystosowane sale lekcyjne są inhibitorami kreatywnych zachowań uczniów. Przeciwnego zdania są pozostałe nauczycielki. Ich zdaniem, twórczy nauczyciel jest w stanie sam przygotować niezbędne materiały i zrobić coś z niczego. Może przy tym korzystać z pomysłowości dzieci. Katarzyna uważa także, że zbyt duża liczba przedmiotów, z których korzysta współczesne dziecko zamiast stymulować, blokuje jego wyobraźnię oraz kreatywność. Nauczycielki (Elżbieta i Martyna) wskazują także antytwórcze zachowania rodziców, do których zaliczają nadmierną ambicję, narzucanie dzieciom swojego zdania i sposobu postrzegania rzeczywistości. Kolejnym inhibitorem kreatywnych zachowań uczniów, który pojawia się w narracjach jest program nauczania oraz podręcznik. Nauczyciele muszą w określonym czasie zrealizować podstawę programową i mają ograniczone możliwości wprowadzania własnych inicjatyw. Rodzice, dyrekcja oraz władze oświatowe oczekują wysokich wyników nauczania. Nauczyciele skupiają się zatem przede wszystkim na przygotowywaniu uczniów do egzaminów, zaniedbując inne obszary ich rozwoju.

\section{Podsumowanie}

Wiedza nauczycieli o twórczości i ich wrażliwość pełnią istotną rolę w rozwijaniu kreatywnych zachowań uczniów w środowisku szkolnym. Nauczycielki preferujące twórcze orientacje życiowe dostrzegają przejawy kreatywności dzieci w pracach plastycznych, pisemnych, zabawach ruchowych oraz występach artystycznych. Twórcze osiągnięcia dzieci prezentują przede wszystkich na wystawach oraz dekoracjach, 
a także wysyłają na konkursy i przeglądy organizowane przez różne placówki i instytucje. W ich narracjach dotyczących opisu twórczego ucznia pojawiają się różne cechy, ale są one zgodne z teoriami naukowymi w tym zakresie. Do najważniejszych inhibitorów kreatywności uczniów zaliczają przede wszystkim osobowość nauczyciela oraz styl jego pracy, destrukcyjne zachowania rówieśników, a także program nauczania (tabela 2).

Tabela 2. Twórczość uczniów klas początkowych w opinii nauczycielek

\begin{tabular}{|l|l|}
\hline \multicolumn{1}{|c|}{ Kryteria analizy } & $\begin{array}{l}\text { Wskazania nauczycielek preferujących } \\
\text { twórcze orientacje życiowe }\end{array}$ \\
\hline Przejawy twórczości uczniów & $\begin{array}{l}\text { Prace plastyczne } \\
\text { Prace pisemne } \\
\text { Zabawy ruchowe } \\
\text { Występy artystyczne }\end{array}$ \\
\hline Inhibitory twórczości uczniów & $\begin{array}{l}\text { Osobowość nauczyciela i styl jego pracy } \\
\text { Zachowania innych uczniów } \\
\text { Program nauczania }\end{array}$ \\
\hline $\begin{array}{l}\text { Formy prezentowania } \\
\text { twórczych osiągnięć uczniów }\end{array}$ & $\begin{array}{l}\text { Wystawy } \\
\text { Dekoracje } \\
\text { Konkursy } \\
\text { Przeglądy }\end{array}$ \\
\hline Cechy twórczego ucznia & $\begin{array}{l}\text { Zróżnicowane cechy, ale obraz twórczego } \\
\text { ucznia jest zgodny z teoriami naukowymi }\end{array}$ \\
\hline
\end{tabular}

Źródło: badania własne.

W wyniku przeprowadzonych analiz można stwierdzić, że preferencje nauczycieli w zakresie twórczych orientacji życiowych sprzyjają tworzeniu w klasie klimatu odpowiedniego do podejmowania działań twórczych. Stosunek nauczycielek do twórczości dziecięcej zaprzecza wizerunkowi nauczyciela, który traktuje „twórczość jako aktywność niewygodną, absorbującą nadmiernie nauczyciela”39. Dostrzegają one twórczość uczniów w różnych formach dziecięcej aktywności, a także prezentują jej efekty w środowisku lokalnym. Większość podejmowanych przez nie działań sprzyja dziecięcej kreatywności, jednak w ich

39 K.J. Szmidt, Edukacyjne uwarunkowania rozwoju kreatywności, Wydawnictwo Uniwersytetu Łódzkiego, Łódź 2017, s. 19. 
wypowiedziach pojawiają się także kwestie, które ujawniają pewne braki w wiedzy dotyczącej twórczości.

\begin{abstract}
Children's creativity, which stimulates all of the cognitive and emotional processes, influences the development of their personality. It is also a natural therapeutic instrument as a child expresses their own thoughts and feelings through the process of creation. Literature distinguishes four main areas of children's creativity: artistic, verbal, musical, and kinaesthetic. Both teachers' knowledge on creativity and their sensitivity play a key role in the development of creativity in children within the school environment. This article presents my own qualitative research results on the perception of creativity of first stage students by their teachers. Six participants with strong preference for artistic tendencies were examined in the study. The conducted analysis showed that teachers' preferences for artistic tendencies support an atmosphere suitable for artistic activities within the classroom.
\end{abstract}

\title{
Bibliografia
}

Cudowska A., Twórcze orientacje życiowe w dialogu edukacyjnym. Studium teoretyczno-empiryczne, Wydawnictwo Trans Humana, Białystok 2014.

Cudowska A., Twórczość pedagogiczna nauczyciela w społeczeństwie wiedzy, [w:] W. Horyń, J. Maciejewski (red.), Nauczyciel andragog w społeczeństwie wiedzy, Wydawnictwo Uniwersytetu Wrocławskiego, Wrocław 2007.

Dobrołowicz J., Kreatywność uczniów a ich osiaggnięcia szkolne, Wydawnictwo Akademii Świętokrzyskiej, Kielce 2002.

Dziedziewicz D., Śladami wyobraźni twórczej. Bajka i działania plastyczne jako metody stymulowania $i$ analizowania twórczości najmłodszych, [w:] M. Karwowski, A. Gajda (red.), Kreatywność (nie)tylko w klasie szkolnej, Wydawnictwo Akademii Pedagogiki Specjalnej, Warszawa 2010.

Gloton R., Clero C., Twórcza aktywność dziecka, przek. I. Wojnar, WSiP, Warszawa 1985.

Gnitecki J., Grochowalska B., Problematyka metodyczna rozwijania aktywności twórczej w nauczaniu początkowym. Kultura fizyczna, [w:] J. Kujawiński (red.), Rozwijanie aktywności twórczej uczniów klas początkowych. Zarys metodyki, WSiP, Warszawa 1990. 
Guzy O., Twórcza aktywność werbalna ucznia a kompetencje przestrzenne, [w:] B. Myrdzik, M. Karwatowska (red.), Twórczość w szkole. Rzeczywiste $i$ możliwe aspekty zagadnienia, Wydawnictwo Uniwersytetu Marii Curie-Skłodowskiej, Lublin 2011.

Gąsiorek K., Uczeń w wieku wczesnoszkolnym jako twórca języka, [w: B. Myrdzik, M. Karwatowska (red.), Twórczość w szkole. Rzeczywiste $i$ możliwe aspekty zagadnienia, Wydawnictwo Uniwersytetu Marii Curie-Skłodowskiej, Lublin 2011.

Kaźmierczak A., Wychowawcza rola zabaw i gier ruchowych w opinii nauczycieli kształcenia zintegrowanego, [w:] W. Leżańska (red.), Nauczyciel wczesnej edukacji w kontekście zmian edukacyjnych, Wydawnictwo Uniwersytetu Łódzkiego, Łódź 2009.

Klim-Klimaszewska A., Twórcza aktywność, [w:] T. Pilch (red.), Encyklopedia pedagogiczna XXI wieku, t. 6, Wydawnictwo Akademickie Żak, Warszawa 2007.

Kujawiński J., Rozwijanie aktywności twórczej uczniów klas początkowych, [w:] J. Kujawiński (red.), Rozwijanie aktywności twórczej uczniów klas poczatkowych. Zarys metodyki, WSiP, Warszawa 1990.

Kujawiński J., Wstęp, [w:] J. Kujawiński (red.), Rozwijanie aktywności twórczej uczniów klas początkowych. Zarys metodyki, WSiP, Warszawa 1990.

Kędzierska A., Formy muzycznej aktywności twórczej na zajęciach kształcenia słuchu, [w:] S. Popek, R.E. Bernacka, C.W. Domański, B. Gawda, D. Turska, A.M. Zawadzka (red.), Psychologia twórczości. Nowe horyzonty, Wydawnictwo Uniwersytetu Marii Curie-Skłodowskiej, Lublin 2009.

Łączyk M., Środowisko wychowawcze a osobowość twórcza - diagnoza uwarunkowań postaw twórczych studentów na podstawie badań własnych, [w:] S. Popek, R.E. Bernacka, C.W. Domański, B. Gawda, D. Turska, A.M. Zawadzka (red.), Psychologia twórczości. Nowe horyzonty, Wydawnictwo Uniwersytetu Marii Curie-Skłodowskiej, Lublin 2009.

Magda-Adamowicz M., Twórczość pedagogiczna nauczycieli w kontekście systemowym. Źródła, koncepcje, identyfikacje, Wydawnictwo Adam Marszałek, Toruń 2015.

Magda-Adamowicz M., Uwarunkowania efektywności kształcenia nauczycieli klas I-III w zakresie twórczości pedagogicznej, Oficyna Wydawnicza Uniwersytetu Zielonogórskiego, Zielona Góra 2009.

Marek E., Nauczyciel wczesnej edukacji w zmieniajaccej się szkole, [w:] B. Muchacka, M. Szymański (red.), Nauczyciel w świecie współczesnym, Oficyna Wydawnicza „Impuls”, Kraków 2008. 
Mielech A., Twórczość językowa dziecka w okresie wczesnoszkolnym, [w:] R. Piwowarski (red.), Dziecko - sukcesy i porażki, Instytut Badań Edukacyjnych, Warszawa 2007.

Miles M.B., Huberman A.M., Analiza danych jakościowych, przekł. S. Zabielski, Wydawnictwo Trans Humana, Białystok 2000.

Niesporek-Szamburska B., Pisanie baśni - od motywacji do kształcenia kompetencji tekstotwórczej, [w:] B. Myrdzik, M. Karwatowska (red.), Twórczość w szkole. Rzeczywiste i możliwe aspekty zagadnienia, Wydawnictwo Uniwersytetu Marii Curie-Skłodowskiej, Lublin 2011.

Nęcka E., Psychologia twórczości, GWP, Gdańsk 2003.

Okoń W., Nowy słownik pedagogiczny, Wydawnictwo Akademickie Żak, Warszawa 2004.

Okoń W., Zabawa a rzeczywistość, Wydawnictwo Akademickie Żak, Warszawa 1987.

Okraska M., Stymulowanie twórczości plastycznej dzieci w wieku przedszkolnym, [w:] A. Tyl (red.), Nauczyciel wczesnej edukacji wobec zmieniającej się rzeczywistości edukacyjnej, kulturowej i społecznej, Wydawnictwo Uniwersytetu Łódzkiego, Łódź 2011.

Pilch T., Zasady badań pedagogicznych, Wydawnictwo Akademickie Żak, Warszawa 1998.

Pomirska Z., Strategia ludyczna w rozwijaniu twórczości językowej dzieci i młodzieży, [w:] B. Myrdzik, M. Karwatowska (red.), Twórczość w szkole. Rzeczywiste i możliwe aspekty zagadnienia, Wydawnictwo Uniwersytetu Marii Curie-Skłodowskiej, Lublin 2011.

Przetacznik-Gierowska M., Tyszkowa M., Psychologia rozwoju człowieka, Wydawnictwo Naukowe PWN, Warszawa 1996.

Przybyła O., Kompetencje tekstotwórcze uczniów klas poczatkowych $w$ świetle sensoryczno-motorycznego kształcenia dla mowy $i$ języka, [w:] B. Myrdzik, M. Karwatowska (red.), Twórczość w szkole. Rzeczywiste $i$ możliwe aspekty zagadnienia, Wydawnictwo Uniwersytetu Marii Curie-Skłodowskiej, Lublin 2011.

Szmidt K.J., Edukacyjne uwarunkowania rozwoju kreatywności, Wydawnictwo Uniwersytetu Łódzkiego, Łódź 2017.

Szmidt K.J., Mity na temat twórczości dzieci i próba ich dekonspiracji, [w:] K.J. Szmidt, W. Ligęza (red.), Twórczość dzieci i młodzieży. Stymulowanie, badanie, wsparcie, Ośrodek Twórczej Edukacji „Kangur", Kraków 2009.

Szmidt K.J., Pedagogika twórczości, GWP, Gdańsk 2007.

Turska D., Dynamika postawy twórczej a typ kształcenia szkolnego młodzieży, Wydawnictwo Uniwersytetu Marii Curie-Skłodowskiej, Lublin 1994. 
Turska D., Nihil novi w edukacji. Rzecz o kreatywnym prymusie polskiej szkoły okresu reform, [w:] W. Dobrołowicz, K.J. Szmidt, I. Pufal-Struzik, U. Ostrowska, J. Gralewski (red.), Kreatywność kluczem do sukcesu w edukacji, Wszechnica Polska Szkoła Wyższa Towarzystwa Wiedzy Powszechnej, Warszawa 2006.

Uszyńska-Jarmoc J., Twórcza aktywność dziecka. Teoria-rzeczywistośćperspektywy rozwoju, Wydawnictwo Trans Humana, Białystok 2003. 